\title{
Giorgos Katsambekis and Alexandros Kioup- kiolis (eds.), Radical Democracy and Collective Movements Today: The Biopolitics of the Multitude Versus the Hegemony of the People
}

Farnham: Ashgate, 2014, 247pp., ISBN 978-1409470526

\author{
Reviewed by Maria Kochkina \\ European University at St. Petersburg
}

The book Radical Democracy and Collective Movements Today: The Biopolitics of the Multitude Versus the Hegemony of the People was conceived by its editors, Giorgos Katsambekis and Alexandros Kioupkiolis, as a contribution to one of the major debates in contemporary political theory. Recent popular mobilizations (the indignados in Spain, the aganaktismenoi in Greece, Occupy Wall Street, the Arab Spring, among others) carry a number of prominent features such as a horizontal principle of organization, Internet-based communication strategies, the lack of a leading group or personalities, spontaneity, etc., which is believed to be a sign of a shift from the usual patterns of political and social struggle to new forms of insurgent engagement. Attempts to analyze these movements are marked by the authors of the volume as falling into either of two possible theoretical perspectives. The dichotomy is put in the title of the collection: the biopolitics of the multitude versus the hegemony of the people. Based on the dimension of the debate, the antagonism acquires different names throughout the book: transcedence versus immanence, politics versus biopolitics, verticality versus horizontality, hegemony versus autonomy, and so on. This opposition, which concerns theoretical and practical matters, is often set as a starting point in the chapters of the book.

The domain in which the discussion takes place is commonly called "post-Marxism" by the authors, by which they mean an approach that foregoes a classical class struggle understanding of social dynamics. Within the context of the present book the discussion revolves around two theoretical developments. Ernesto Laclau and his progeny shift their analysis toward the cultural side of social antagonism and the field of discourse, following the course taken by Antonio Gramsci who brought about 
the conception of hegemony (e.g., see Laclau and Mouffe 2001). The second model is elaborated mostly by Antonio Negri and Michael Hardt in their trilogy (Hardt and Negri 2001, 2004, 2009), and other autonomist thinkers. These authors make a transition from the orthodox Marxist view by considering processes in contemporary society as a result of the unceasing expansion of capital and a change in the mode of production that becomes biopolitical. It is assumed that the choice between these two conceptions in relation to contemporary social movements has two major implications. First, it is a matter of description and understanding current events. Second, it is a question of political strategy and the future development of social struggle.

The volume consists of ten chapters and an introduction by the editors. Among the authors of the essays there are thinkers who are affiliated with either or none of the "camps." Most chapters summarize and discuss both perspectives which makes a lot of points reoccur in the book. One can hardly discern any particular logic behind the structure of the collection because it does not have a systematizing principle. Apparently the editors' intention was to give space for varied and even conflicting voices to be heard and they have truly succeeded in that.

Benjamin Arditi's chapter "Post-Hegemony: Politics Outside the Usual Post-Marxist Paradigm” (17-44) and Seal Newman's “Occupy and Autonomous Political Life" (93-110) attempt to demonstrate the limitations that hegemony theory faces when trying to explain contemporary movements and to show how an autonomist perspective can grasp the change taking place. Arditi (17-44), for example, criticizes a tendency in Laclau and Mouffe's work to narrow down all forms of political activity to hegemonic practices, which does not leave any room for alternative political projects. He argues that the new forms of popular mobilization extend political space for new modes of insurgent participation which he calls post-hegemony.

Richard Day and Nick Montgomery's essay, "Letter to a Greek Anarchist: On Multitudes, Peoples and New Empires" (45-72) argue that it is important for political theory to interact with and even to be addressed to agents of social and political change. Although the authors clearly stand on an autonomist position, they criticize the notion of multitude as they claim that there is a hegemonic moment in it quite contrary to the aspiration of the authors, who take the biopolitical position including Hardt and Negri themselves (51-59). Abandoning the concept of multitude as a new reincarnation of universal revolutionary subject clears space for studying local political subjectivities, in this case the indigenous struggles that are viewed by the authors as tokens of Exodus. Although this chapter contains an interesting critique of Hardt and Negri's theory, it also reveals an oversimplifying attitude when it comes to Day's and Montgomery's own original approach to explaining political reality. Despite discussing indigenous movements, little is said about their own organizational forms and 
in what ways they are an alternative to empire beyond the opposition between the local and the global. This results in the claim that there is no difference between multitude and empire. Although Day and Montgomery recognize the contradictory character of the conception of empire, their particular attempt to solve its problems from within is dubious. Third, the point of addressing the insurgent actors seems to be forgotten toward the end of chapter as it is not clear how they would benefit of such a twist in autonomist theory.

Jodi Dean's contribution, “Sovereignty of the People" (73-92), is also critical of Hardt and Negri's concept of multitude for being too universal and not accounting for the internal antagonism that exists in any kind of movement. In her essay she seeks to offer a new concept which would make the discussion take a step beyond the dichotomy and be constructive for the issue of contemporary radical struggle. She writes that in the present circumstances the proletariat can not embrace the variety of ways in which insurgency appears and it does not fit today's circumstances. The proletariat is just a historically specific form of a broader kind of alliance that is of the people. She turns to Jacques Rancière to introduce a concept of "the-people-as-the-rest-of-us" could overcome this inadequacy and become a name for a contemporary revolutionary subject (76).

Yannis Stavrakakis' contribution, "Hegemony or Post-Hegemony? Discourse, Representation and the Revenge(s) of the Real" (111-32) is dedicated to retorting the critique of Laclau's theory from an autonomist perspective. Little is said about the movements and the claims of the other camp here. However, the subtle, detailed, and elaborate take on the theory of hegemony makes the essay a breath of fresh air in a collection of very similar contributions. Stavrakakis shows that the rejection of hegemony theory and its critique stems partially from an oversimplification and disregard of movements' and researchers' own ideological prejudice.

Kioupkiolis (149-68) and Katsambekis (169-90) both try to go beyond the opposition, proposing notions like "hegemony of the multitude" (Kioupkiolis, 149) or "multitudinous people" (Katsambekis, 184). Although the desire to bring together both theories is understandable, it remains unclear how to converge approaches with such different ontological prerequisites. The possibility of their compatibility is reasonably questioned by Paul Reknet in Chapter 6. It seems that the conceptions in their analysis are to be applied to quite different planes of politics and those new proposed concepts add little to help understand the configuration of their relations. This result leaves the reader with an impression of a sort of a trickery as the editors and authors first strictly set the dichotomy and then cumulatively solve it, offering it as a result instead of asking whether there is a dichotomy at all and why we should think so in the first place. 
While the authors are critical of each other and of the other camp's views, they are mostly overtly sympathetic to the movements. There are certainly some common ways in which these movements appear but there is also a divergence in what they aim at. It is important to realize that there are differences between organizational forms and discourse, aims, and self-positioning of the movements even though some of them look morphologically similar. The "multitudinous" being of the movements influence ways of political involvement that become less a collective action and more a connective one (Bennett and Segerberg, 2012), and is sometimes accompanied by ideological leftism, but this is not necessarily so. The authors' aspirations for the volume might be too radical or even contradictory to the actors,' as there are alternative projects inside these movements. While Ukrainian and Russian protests bear some resemblance to the Arab Spring and apparently borrowed some protest practices from movements like Occupy, they can hardly can be called anticapitalist, just like the Arab Spring itself. How do we separate one type of protest from the other if it is all about organization and not about ideology? If we do not discuss this kind of question we are left without a context only to engage in a hegemonic contention "aiming at securing the consent of prospective readers," as Stavrakakis puts it (120). Like Stavrakakis, other contributors such as Alex Knott (191-212), and Maria Prentoilis and Lasse Thomassen (213-34), attempt to demonstrate that the multitudinous being of contemporary uprising is itself some sort of belief that not only radical intellectuals but members of the movements adopt. These authors see it as a productive idea, which can be put into practice and effectively transform these movements. It would be a good conclusion if we knew how this could work and there was not only discursive and strategic but also an ontological claim connected with this view.

This book is an important attempt to answer questions of contemporary politics but it turns out inconclusive. One would think that a volume dedicated to a single problem could thoroughly organize existing views but instead the reader is left with a multiplication of them. The motto of the whole book is supposed to be "let's return to politics" as the introduction suggests (14), but it sounds incompatible with the feelings left after reading the volume. To what kind of politics are we supposed to get back to? Do we need to wait until some sort of political teleology realizes itself and solves our analytical predicaments? If it is all about practice why do we need more than two hundred pages of analysis and critique? While this book deserves praise for staking out a bold theoretical agenda overall, its major strength is not a single message that it delivers, but its particularity and detailed criticism of two popular perspectives on contemporary social movements in political theory. 


\section{Book reviews / Рецензии}

\section{Bibliography}

Bennett, Lance and Alexandra Segerberg (2012). “The Logic of Connective Action: Digital Media and the Personalization of Contentious Politics.” Information, Communication and Society 15.5: 739-68.

Hardt, Michael and Antonio Negri (2001). Empire. Cambridge, MA: Harvard University Press.

Hardt, Michael and Antonio Negri (2004). Multitude: War and Democracy in the Age of Empire. London: Penguin Books.

Hardt, Michael and Antonio Negri (2009). Commonwealth. Cambridge, MA: Harvard University Press.

Laclau, Ernesto and Chantal Mouffe (2001). Hegemony and Socialist Strategy: Toward a Radical Democratic Politics. London: Verso. 